by Sylvi Haldorsen ${ }^{1}$, Martine J. van der Ploeg ${ }^{2}$, Dioni I. Cendón ${ }^{3,4}$, Jianyao

Chen ${ }^{5}$, Najiba Chkir Ben Jemâa ${ }^{6}$, Jason J. Gurdak ${ }^{7}$, Roland Purtschert ${ }^{8}$, Ofelia Tujchneider ${ }^{9}$, Rein Vaikmäe ${ }^{10}$, Marcela Perez ${ }^{9}$, and Kamel Zouari ${ }^{6}$

\title{
Groundwater and Global Palaeoclimate Signals (G@GPS)
}

${ }^{1}$ Norwegian University of Life Sciences, Department of Environmental Sciences, P.O.Box5003, N-1433 AAs, Norway. E-mail: sylvi.haldorsen@nmbu.no

${ }^{2}$ Wageningen University, Centre for Soil Science Soil Physics and Land Management Group P.O. Box 47, 6700AA Wageningen, The Netherlands. E-mail: martine.vanderploeg@wur.nl

3 Australian Nuclear Science and Technology Organization (ANSTO), Locked Bag 2001, Kirrawee DC, NSW 2232 Australia. E-mail:dce@ansto.gov.au

${ }^{4}$ Connected Water Initiative, School of Biological, Earth and Environmental Sciences, University of New South Wales (UNSW), Sydney, Australia.

${ }^{5}$ Department of Water Resources and Environment, School of Geography and Planning, Sun Yatsen University, 135 Xingang Xi Road, Haizhu District, Guangzhou 510275. China, E-mail: chenjyao@mail.sysu.edu.cn or chenjianyao@hotmail.com

${ }^{6}$ Lab. of Radio-Analyses and Environment of the National School of Engineering, Adress : BP 1173 - Route de Soukra - 3038Sfax Tunisie.E-mail:najiba_chkir@yahoo.fr; kamel.zouari@enis.rnu.tn

${ }^{7}$ Department of Earth \& Climate Sciences, San Francisco State University, 1600 Holloway Avenue, San Francisco, CA, USA. E-mail: jgurdak@sfsu.edu

${ }^{8}$ Climate and Environmental Physics, Physics Institute, University of Bern, Sidlerstrasse 5, 3012 Bern, Switzerland. E-mail: purtschert@climate.unibe.ch

${ }^{9}$ Faculty of Engineering and Water Sciences. NationalUniversity El Litoral. Ciudad Universitaria. Ruta Nacional 168 - Km.472,4. S300. Santa Fe. Argentina.E-mail: ofeliatujchneider@yahoo.com.ar; pichy@fich.unl.edu.ar; perezmarcelaa@gmail.com

${ }^{10}$ Institute of Geology, Tallinn University of Technology, 5 Ehitajate tee, 19086 Tallinn, Estonia.E-mail: Rein.Vaikmae@ttu.ee

(Received: 06/10/2015; Accepted: 29/2/2016)

DOI:10.18814/epiiugs/2016/v39i4/103888

Groundwater sources supply fresh drinking water to almost half of the World's population and are a main source of water for irrigation across world. Characterization of groundwater resources, surfacegroundwater interactions and their link to the global water cycle and modern global change are important themes in hydrogeological research, whereas little attention has been given to the relation between groundwater and past climate variations. A groundwater system's history is vital to assess its vulnerability under future and potentially adverse climatic changes. The scientific initiative Groundwater and Global Palaeoclimate Signals (G@GPS) investigates major recharge periods of large groundwater aquifers worldwide. We describe the findings for a major basin on each permanently inhabited continent and one with coastal influences in Australia. As palaeo-signals in groundwater are inherently low-resolution records, they can only be related to considerable amounts of recharge. Long periods with substantial groundwater recharge ought to be well identifiable in terrestrial records. Correlation with regional and global climate records may give ideas of the conditions under which such large amounts of recharge were initiated.

\section{Introduction}

Groundwater abstraction in many aquifers worldwide has surpassed a sustainable yield. Increased need of water for human consumption and irrigation increases the water demand continuously (Aeschbach-Hertig and Gleeson, 2012). In some aquifers very limited modern recharge takes place, with available groundwater recharged over long time and under very different climates in the past. Some of these groundwater systems may be used as palaeoclimate proxies, with information about major recharge episodes in the past. This is particularly true for low-recharge aquifers, where groundwater often has long transit times. The stored information in these groundwater systems may record climatic information such as groundwater recharge temperature, rainfall sources and rainfall intensities. Linked to a 
chronological record these provide a framework to assess aquifer recharge-history and its vulnerability or resilience to future climatic changes or increased groundwater extraction (e.g. Edmunds et al., 2004). However, many processes such as dispersion and/or waterrock interactions, which occur along the entire groundwater pathway from its recharge to discharge area, can make palaeoclimate signals difficult to interpret accurately. Therefore, palaeoclimate information deduced from groundwater is inherently a low-resolution record that offers a window to understand recharge dynamics of the aquifers we rely upon.

Over the last few years, a number of high-resolution continentalscale palaeoclimate records have been published from all continents. With improved analytical techniques and wider analysis of environmental isotopes in groundwater, a wealth of information is now emerging globally from a number of aquifers. Earlier palaeoclimate information was mainly based on stable water isotopes $\left(\delta^{18} \mathrm{O}, \delta^{2} \mathrm{H}\right)$ and age determinations of groundwater on ${ }^{3} \mathrm{H}$ and ${ }^{14} \mathrm{C}$ contents. Today a number of additional palaeoclimate parameters, such as noble gases and different stable isotopes, and dating methods based on radioactive isotopes such as ${ }^{3} \mathrm{H} /{ }^{3} \mathrm{He},{ }^{32} \mathrm{Si},{ }^{81} \mathrm{Kr},{ }^{85} \mathrm{Kr}$ and ${ }^{36} \mathrm{Cl}$ are available.

The scientific initiative G@GPS (Groundwater and Global Palaeoclimate Signals) was launched in 2011 with support from the IUGS/UNESCO International Geoscience program (IGCP-618), INQUA (International Union for Quaternary Research) and the GRAPHIC project under the UNESCO International Hydrological Program. The major task is to identify major recharge periods of large groundwater aquifers worldwide and to correlate the results regionally, continentally and perhaps globally. Initially one or two emblematic aquifers ("flag basins") have been targeted on each continent (Fig. 1) where pre-existing research can be accessed and/or a small number of additional analyses may add substantial value. The overall aim of the initiative is to compare and potentially correlate major climatic events derived from these basins with those obtained from higher resolution continental proxy records. Here, we provide the first results from the seven "flag basins".

\section{Africa}

The Northwest Sahara Aquifer System (NWSAS) covers an area of over 1 million km² (Fig. 2) and is shared between Algeria, Libya, and Tunisia. This large basin is multilayered, with the Upper Cretaceous to Cenozoic Complex Terminal (CT) and the deeper Lower Cretaceous Continental Intercalaire (CI) forming the most important aquifer systems. The estimated water reserve is $\sim 3 \times 10^{7} \mathrm{~m}^{3}$ (OSS, 2003). The thickness of NWSAS varies and in the most productive part, the CI, is more than $100 \mathrm{~m}$ thick (Fig. 3). Some recharge occurs today in the Algerian SW Atlas Mountains and in Dahar in Tunisia, but most of the water in the CI is non-renewable and recharge occurred under climate conditions that prevailed thousands of years ago. There is a marked groundwater convergence toward the Chott region in SE Tunisia (Fig. 3; Edmunds et al., 2003), where artesian water flowing up to the surface evaporates or is used for irrigation.

The NWSAS is the most important water resource in the desert and semi-desert area of Northwest Sahara. With increasing population and increased water needs, the pressure on groundwater has become critical. A recent survey of the basin showed alarming withdrawals. A drop in the piezometric water level of the CI of $1 \mathrm{~m} \mathrm{a}^{-1}$ has been reported (Abid et al., 2012) in the central part, and overexploitation of the CT has in some areas resulted in a loss of the artesian conditions (Kamel et al. 2005).

Multiple parameters were used to investigate the groundwater and environmental change in NWSAS, including major elements, $\delta^{18} \mathrm{O}, \delta^{2} \mathrm{H}, \delta^{13} \mathrm{C},{ }^{14} \mathrm{C},{ }^{234} \mathrm{U},{ }^{238} \mathrm{U},{ }^{36} \mathrm{Cl}$ and ${ }^{4} \mathrm{He}$. Tracer age determinations in $\mathrm{CI}$ groundwaters generally indicate modern to Holocene water from the recharge area in the southwest Atlas to Guerrara 200-300 km further east (Fig. 3). The same trend is found on the other recharge area from southeast Dahar to Kebili further

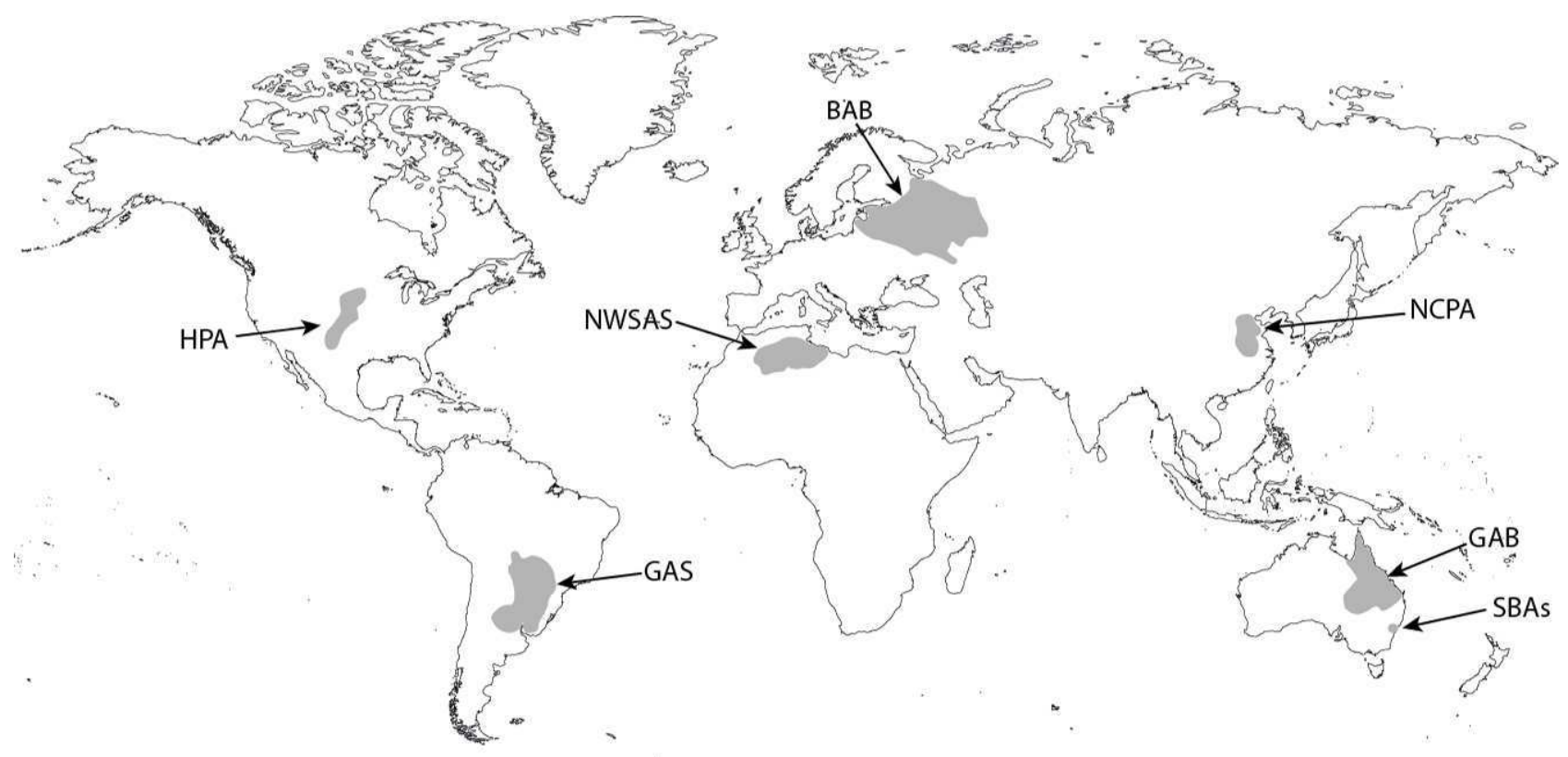

Figure 1. Geographic location of large groundwater basins ("Flag basins") studied in the initiative "Groundwater and Global Palaeoclimate signals”. NWSAS: Northwest Sahara Aquifer System, NCP: North China Plain Aquifer, BAB: Baltic Artesian Basin, HPA: High Plains aquifer, GAB: Great Artesian Basin, Sydney: Sydney coastal basin, GAS: Guaraní Aquifer System. 


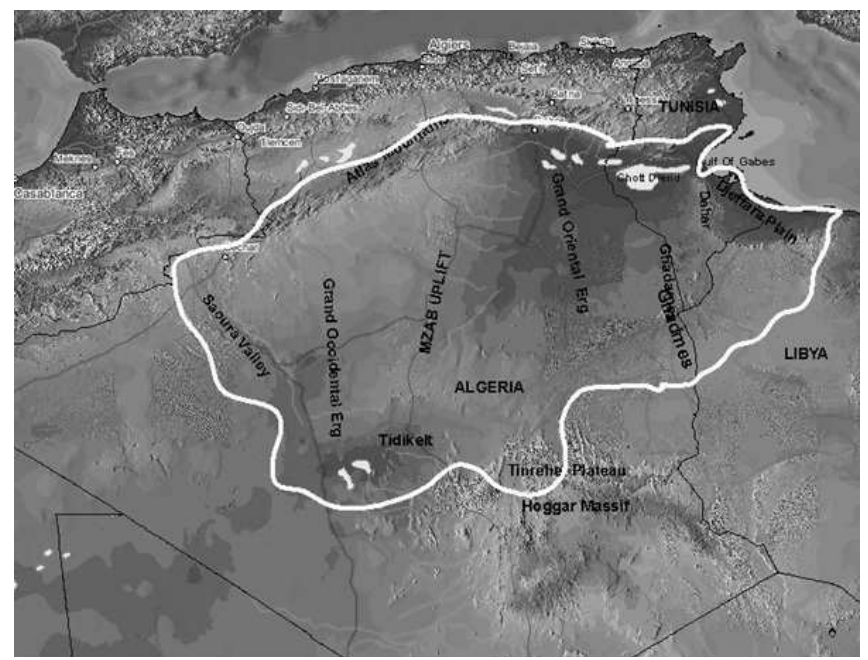

Figure 2. Extent of the Northwest Sahara Aquifer System (NWSAS) and political boundaries.

west. Terrestrial palaeoclimate records from Northwest Africa show that there was a wet period in the Early-Middle Holocene (ca $12 \mathrm{ka}$ BP - $5 \mathrm{ka}$ BP) with continuous vegetation zones in present desert areas (e.g. de Menocal et al. 2000; Kuper and Kröpelin 2006). It is likely that the Holocene water identified in the western- and easternmost parts of the NWSAS recharged during this wet period. However, simulations by Petersen et al. (2014) based on ${ }^{36} \mathrm{Cl}$ analyses indicate that the recharge during the marine isotope stages MIS5 (130 - $92 \mathrm{ka} \mathrm{BP}$ ) and MIS11 (420 - $370 \mathrm{ka} \mathrm{BP)} \mathrm{was} \mathrm{higher} \mathrm{than} \mathrm{in} \mathrm{the}$ Holocene and may have been up to $80 \mathrm{~mm} \mathrm{a}^{-1}$ during pre-Holocene interglacials. In the middle part of the basin, much of the groundwater is too old to be dated by the radiocarbon method and has only been classified as unspecified "Pleistocene" (Abid et al, 2012). Studies by Petersen et al. (2014) indicate that the residence time of the groundwater in the central area may be up to $1 \mathrm{Ma}$.

Geochemical studies show that a mixture between old and modern water takes place, particularly in the CT and the Quaternary groundwater aquifers in southwest Tunisia (e.g. Dassi et al. 2005;

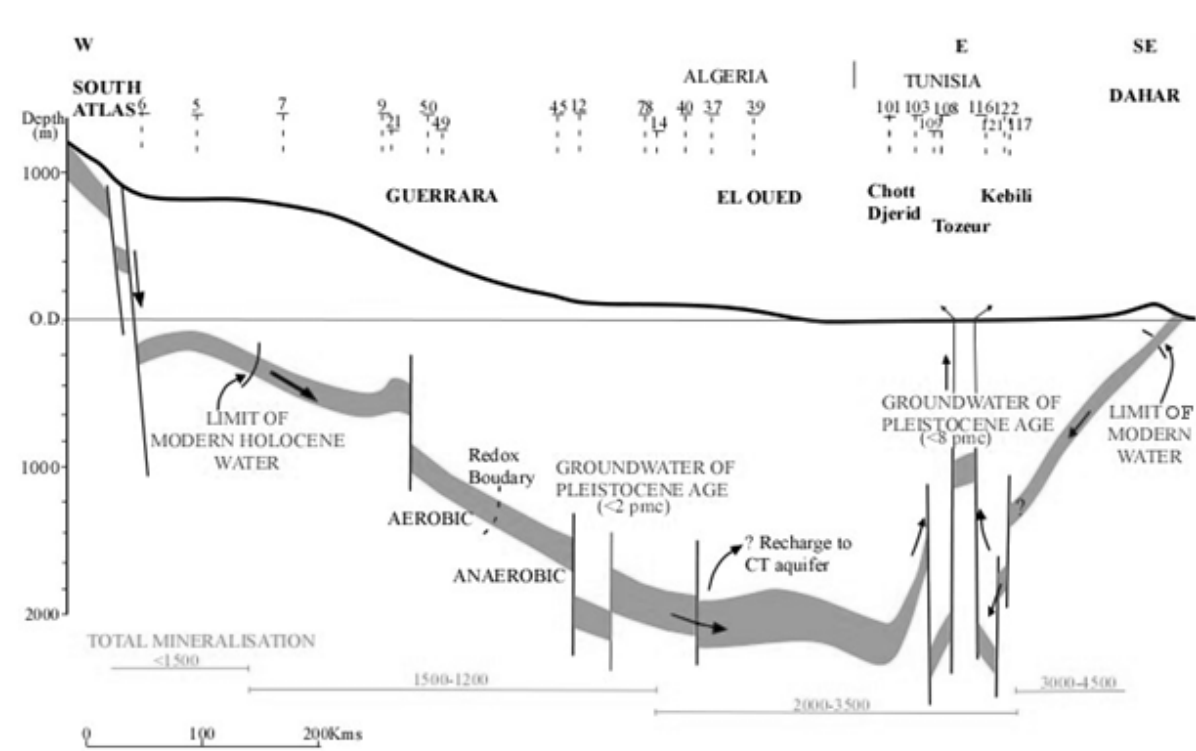

Figure 3. Cross section ( $800 \mathrm{~km}$ ) of the CI flow path from the Algerian Atlas to Dahar area in Tunisia (modified after Edmunds et al., 2003).
Kraiem et al., 2014; Houcine et al. 2014). Radiocarbon dating show modern and Holocene ages in the NW and SE. Current studies carried out with IAEA support using ${ }^{81} \mathrm{Kr}$ are expected to provide more details on groundwater ages.

\section{Asia}

The North China Plain Aquifer (NCP) is located in eastern China, bounded by the Taihang Mountains to the west, the Yanshan Mountains to the north, the Bohai Sea to the east, and the Yellow River to the south. The NCP has only $1.9 \%$ of China's total water resources, but supports $11 \%$ of China's population and $14 \%$ of its arable land (Xie et al., 2002). The NCP is an important agricultural region with groundwater used as the main source for irrigation. The North China Plain was formed through fault subsidence since the Cenozoic and deposition of Quaternary sediments 400-600 m thick by the Yellow River and other main rivers. Four main geomorphologic units can be differentiated in the NCP from the Taihang Mountains to the Bohai Sea: mountain and piedmont plain, alluvial fan plain, flood plain, and coastal plain (Wu et al. 1996). These units are closely associated with various zones of the groundwater flow system (Fig.4). Field surveys and geochemical analyses distinguish a two-layered groundwater structure, the upper younger than $10 \mathrm{ka}$, with a boundary at about 100-150 m depth (Chen et al. 2004). The groundwater flow rate in the last $30 \mathrm{ka}$ was roughly calculated at least as $10 \mathrm{~m} \mathrm{a}^{-1}$ (Chen, 2010).

Groundwater in deep aquifers (>100 $\mathrm{m}$ depth) has ${ }^{14} \mathrm{C}$ ages older than $10 \mathrm{ka}$ (Chen, 2010). Analysis of ${ }^{36} \mathrm{Cl} / \mathrm{Cl}$ in some groundwater samples have resulted in ages of ca. $770 \mathrm{ka}$. However, mixing of ${ }^{36} \mathrm{Cl} / \mathrm{Cl}$ from various sources, with some ${ }^{36} \mathrm{Cl}$ coming from the rocks, is suspected. (Dong et al., 2002). ${ }^{4} \mathrm{He}$ has also been tested to date groundwater ages and relatively consistent results have been obtained comparable to those from ${ }^{14} \mathrm{C}$ (Wei et al., 2011). In order to have a better understanding of factors influencing oxygen isotope composition (Fig. 5) (e.g., temperature or precipitation), noble gases collected from groundwater were used to calculate the recharge temperature and thus differentiate the influences of temperature and monsoon intensity (Kreuzer et al., 2009). Signals from groundwater were compared to high resolution records obtained from stalagmite calcite in two caves Dongge and Hulu, China (Wang et al, 2001; Dykoski et al, 2005), showing a similar pattern in terms of ${ }^{18} \mathrm{O}$ during the period from $15 \mathrm{ka}$ to present.

\section{Europe}

The Baltic Artesian Basin (BAB) with a surface of $\sim 4.8 \times 10^{8} \mathrm{~m}^{2}$ is one of the largest artesian basins in Europe. The BAB covers the territory of Latvia, Lithuania and Estonia, parts of Poland, Russia, and Belarus as well as a large area of the Baltic Sea, including the island of Gotland (Fig. 6A). Geologically, the $\mathrm{BAB}$ is situated in the northwestern part of the East European platform on the southern slope of the Fennoscandian Shield. The bedrock consists mainly of Ediacaran and Paleozoic sedimentary rocks overlying the Paleoproterozoic crystalline basement, which 


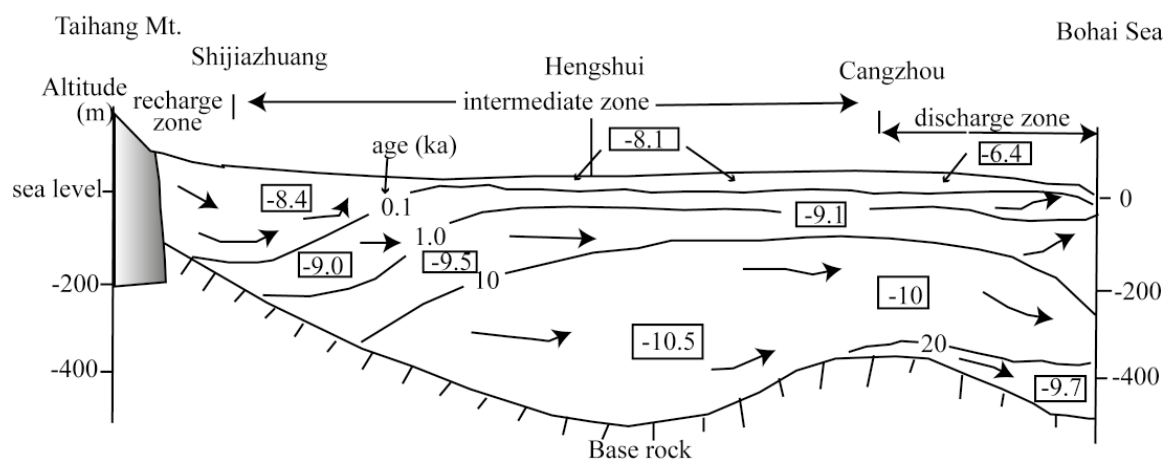

Figure 4. Profile of groundwater flow from the Taihang Mountains to the Bohai Sea in the NCP (modified from Zhang et al. 2000). The hatched area represents the Taihang Mountains, arrows show the direction of groundwater flow, numbers in the boxes are $\delta^{18}$ Ovalues (in \%o) and numbers between lines indicate groundwater age (ka). pressure at the base of the glacier, leading to recharge of glacial meltwater at the northern margin of the BAB (Vaikmäe et al., 2001; Zuzevicius, 2010). During the last million years, the area of the Baltic Basin was subjected to several glaciations, the latest of which ended only $10 \mathrm{ka}$ BP ago (Kalm et al., 2011). During the last glaciation the Scandinavian ice sheet reached the maximum thickness of about $1,000-1,500 \mathrm{~m}$ in the northern part of the basin. The resulting hydraulic gradient was at least $3 \mathrm{~m} \mathrm{~km}^{-1}$ (Jöeleht, 1998), which resulted in a regional groundwater flow -reverse from interglacial flow dynamics. This led to recharge of isotopically light glacial meltwater in Northern Estonia and the Baltic Sea where the aquifer outcrops.

The $\mathrm{Cm}-\mathrm{V}$ system of the $\mathrm{BAB}$ has been

gradually slopes towards the south by $2-4 \mathrm{~m} / \mathrm{km}$. The thickness of the sedimentary cover reaches $5,000 \mathrm{~m}$ in the southwestern part, while the crystalline basement reaches the surface at the northern and southeastern parts of the BAB (Fig. 6B). Hydrogeologically, the BAB is a complex multilayered system where the water in the sedimentary formation can be divided into five aquifer systems separated by three regional aquitards. General groundwater flow in the BAB is from southeast to northwest (Virbulis et al., 2013).

Shallowly buried marginal areas of the Cambrian - Vendian (Cm$\mathrm{V})$ aquifer, particularly in the northern part of the $\mathrm{BAB}$ contain fresh water (total dissolved solids (TDS) $<1000 \mathrm{mg} \mathrm{L}^{-1}$ ), which is the principal and most important source for public water supply in Estonia. However, in most parts of the $\mathrm{Cm}-\mathrm{V}$, especially the deeply buried parts, $\mathrm{Na}-\mathrm{Cl}$ and $\mathrm{Na}-\mathrm{Ca}-\mathrm{Cl}$ brines are found with high salinities (TDS from 50,000 to 200,000 $\mathrm{mg} \mathrm{L}^{-1}$ ). Earlier studies established that the groundwater in the northern part of this system has the most depleted groundwater isotopic composition in Europe $\left(\delta^{18} \mathrm{O}\right.$ values from $-18 \%$ o to $-23 \%$ ) (Punning et al., 1987; Vaikmäe et al., 2001; Mokrik, 1997). These values are much more negative than the reported $-10.4 \%$ o $\delta^{18} \mathrm{O}$ values for ambient precipitation in the area (Punning et al., 1987).

To explain this phenomenon, it was proposed that during the late Weichselian glaciation the Scandinavian ice sheet increased hydraulic

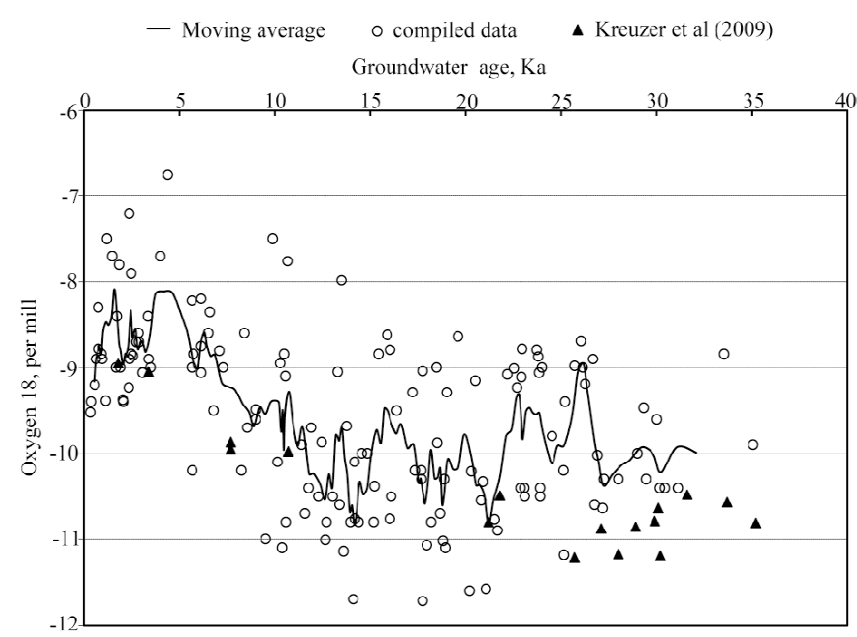

Figure 5. Variations in $\delta^{18} \mathrm{O}$ against ${ }^{14} \mathrm{C}$ (years BP) (modified after Chen, 2010) and complemented with data from Kreuzer et al. (2009). The line represents a 5 data points average. extensively studied using isotopic and geochemical tools $\left({ }^{3} \mathrm{H},{ }^{14} \mathrm{C}\right.$, $\delta^{18} \mathrm{O}, \delta^{13} \mathrm{C},{ }^{39} \mathrm{Ar},{ }^{4} \mathrm{He},{ }^{40} \mathrm{Ar} /,{ }^{36} \mathrm{Ar}$, atmospheric noble gases $(\mathrm{Ne}, \mathrm{Ar}$, $\mathrm{Kr}, \mathrm{Xe})$ for recharge temperature, amount, and composition of extracted gases (Vaikmäe et al., 2001; Karro et al, 2004; Raidla et al. 2012). Recently, ${ }^{81} \mathrm{Kr}$ dating together with the noble gas and isotope analysis has been carried out in the deep brines of the BAB. In brines from Kemeri (Latvia) and Genziai (Lithuania), ${ }^{81} \mathrm{Kr}$ concentrations are below the detection limit $(\mathrm{R} / \mathrm{Ra}=0.02)$ indicating water older than 1.3 Ma (Gerber et al., in prep.). To our knowledge, this is the first groundwater study with ${ }^{81} \mathrm{Kr}$ activities below the detection limit of currently $2 \%$ of the atmospheric ${ }^{81} \mathrm{Kr} / \mathrm{Kr}$ ratio. ${ }^{4} \mathrm{He}$ and ${ }^{40} \mathrm{Ar} /{ }^{36} \mathrm{Ar}$ measurements confirm the generally very high residence time of these waters (Gerber et al., in prep.).

\section{North America}

The High Plains aquifer (HPA) $\left(4.5 \times 10^{8} \mathrm{~m}^{2}\right)$ (Fig. 7) consists of sedimentary deposits that form six hydraulically connected hydrogeologic units, and the most extensive of these units is the Neogene Ogallala Formation (McMahon et al. 2007). The depth to water below land surface ranges from 0 to approximately $152 \mathrm{~m}$, averages about $30 \mathrm{~m}$ (McMahon et al. 2007). The saturated thickness of the High Plains aquifer ranges from less than 1 to more than $300 \mathrm{~m}$ and averages about $60 \mathrm{~m}$ (Fig. 8) (McMahon et al. 2007).

HPA is the most intensively used groundwater resource in the United States (U.S.), producing almost twice the volume of water than any other U.S. aquifer (Maupin and Barber 2005). HPA groundwater supports domestic agricultural production (Dennehy et al. 2002) and is an important virtual water source for grains and other agricultural products (Konikow and Kendy 2005). In 2000, the HPA had an estimated $3.67 \times 10^{12} \mathrm{~m}^{3}$ of drainable water in storage, making it one of the largest aquifers in the world (McGuire, 2007). Since widespread development in the 1940s and '50s, more than half the groundwater in storage in some areas of the HPA has been used (McGuire et al. 2003) because withdrawals greatly exceed recharge rates (McMahon et al., 2007). The largest water-level declines range from 15 to more than $45 \mathrm{~m}$ (Fig. 7). Most (97\%) of the water withdrawn from the HPA is used for irrigation (Maupin and Barber, 2005).

The HPA has a middle-latitude, semi-arid continental climate (average annual air temperature ranges from 4 to $18^{\circ} \mathrm{C}$ ), characterized by moderate average annual precipitation (300 to $840 \mathrm{~mm}$ ) and a 

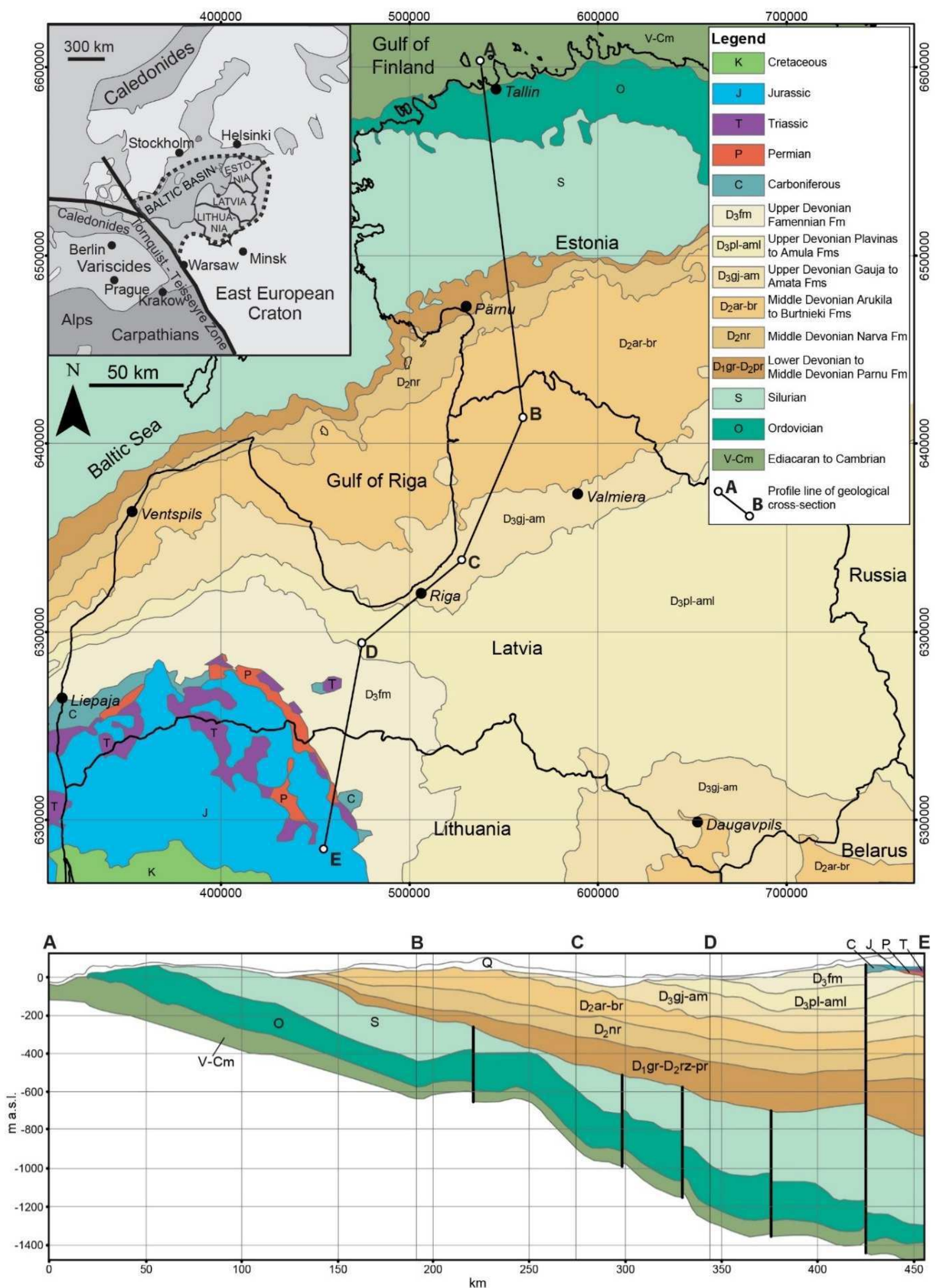

Figure 6. Geological map (A) and cross section (B) of the study region, generated from the geological-hydrogeological model of the Baltic Artesian Basin (Virbulis et al., 2013). 


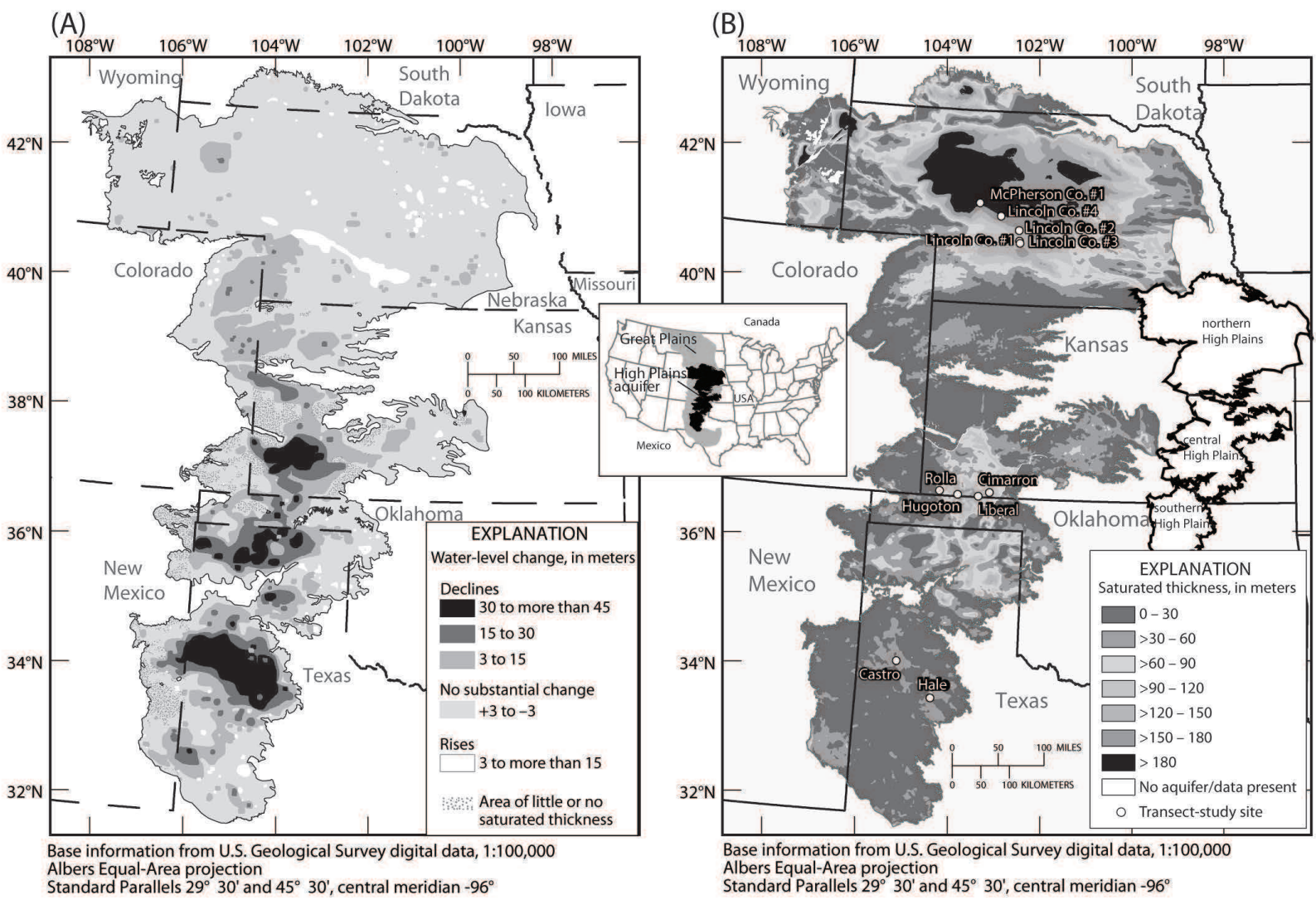

Figure 7. High Plains aquifer (HPA) (A) water level changes from pre-development to 2005 (modified from McGuire (2007) and the High Plains water-level monitoring study), and (B) saturated thickness and locations of regional transect study well nests (modified from Gurdak et al., 2009).

high rate of annual evaporation (1,520 to 2,770 mm) (Gurdak et al., 2012). Because evaporation rates exceed precipitation rates across much of the HPA, little water is available to recharge the aquifer. Recharge occurs by infiltration of irrigation water, aerially diffuse infiltration from precipitation, focused infiltration of storm- and irrigation-water runoff through streambeds and other topographic depressions (Gurdak, 2008; Gurdak et al. 2008; Gurdak and Roe, 2010), and upward movement of water from underlying aquifers. Discharge is primarily to irrigation wells, streams and underlying aquifers, groundwater flow across the eastern boundary of the aquifer, and evapotranspiration.

Vertical gradients in apparent age of groundwater and palaeo-groundwater conditions were studied using regional transects of two to five nested wells sites that were established parallel to regional water-table gradients in areas with some of the largest saturated thicknesses (Fig. 8). The regional transect study design, sample collection, and sample analysis are detailed in McMahon et al. (2004a,b; 2007). The apparent age of water from the regional transect wells was characterized as modern $(<50$ a old based on $>0.5$ tritium units (TU)) or old ( $>50$ a old based on $<0.5 \mathrm{TU}$ ) and by radiocarbon content of dissolved inorganic carbon in groundwater. Groundwater recharge temperatures and concentrations of excess atmospheric gases at the transect sites were also estimated from concentrations of dissolved $\mathrm{Ne}$ and $\mathrm{Ar}$ (McMahon et al., 2004a).

There are two general types of vertical gradients in apparent groundwater age. Groundwater ages systematically increased with depth below the water table in areas with relatively small amounts of

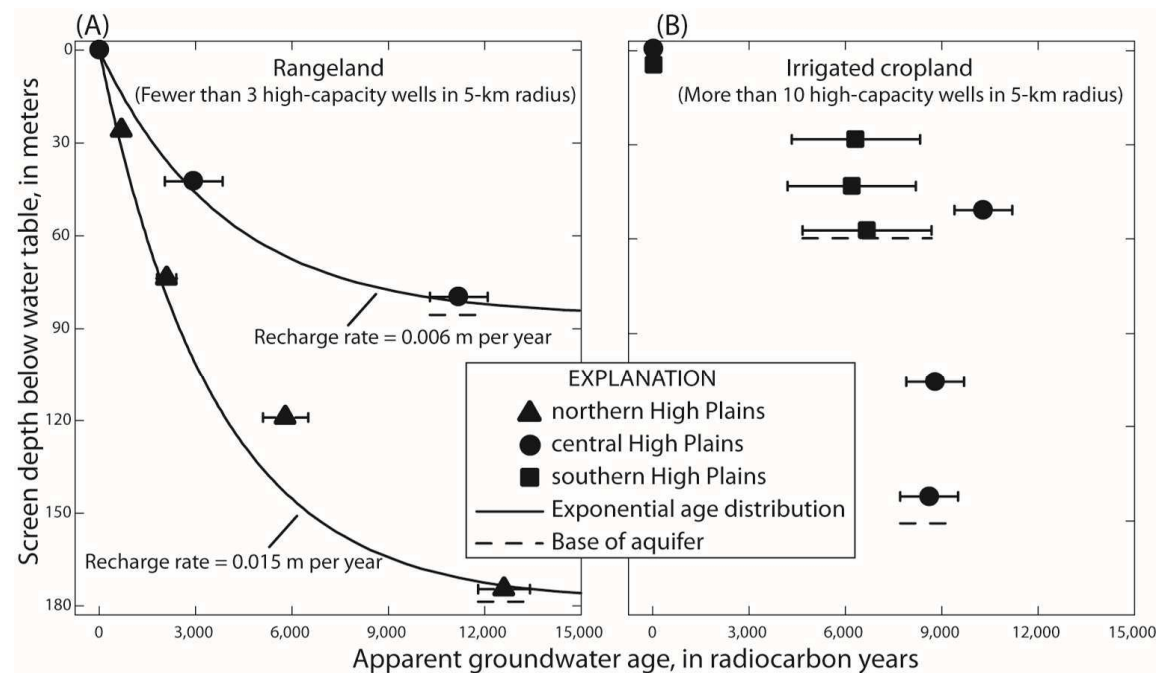

Fig 8. Groundwater age as a function of well-screen depth below the water table of the High Plains Aquifer (HPA) in (A) rangeland settings that have few high-capacity wells and relatively small amount of pumping and $(B)$ irrigated-cropland settings that have numerous high-capacity wells and relatively large amount of pumping (modified from Gurdak et al., 2009 and McMahon et al., 2007). Error bars represent \pm 1 standard deviation from average. 
pumping for irrigation or water supply (Fig. 8A). However, in areas with relatively large amounts of pumping for irrigation or water supply, apparent-age gradients are less evident or non-existent at depths (Fig. $8 \mathrm{~B})$, most likely resulting from vertical mixing of water in the aquifer by pumping wells or vertical leakage in wells having long or multiple well screens (Gurdak et al., 2009; McMahon et al., 2007). At the sites with relatively larger amounts of pumping, vertical mixing affected at least 50 to $65 \%$ of the saturated thickness (Fig. 8B). Findings indicate that old groundwater accounted for 44 to $95 \%$ of the water at the study sites.

Apparent groundwater ages at the base of the aquifer at the transect sites ranged from about 3.4 to $15.6 \mathrm{ka}$ (Fig. 8), which indicates that most of the water at the transect sites consisted of groundwater that recharged prior to human activity. Recharge temperatures calculated using the dissolved $\mathrm{Ne}$ and $\mathrm{Ar}$ indicate a shift from cooler to warmer conditions occurred after about $9 \mathrm{ka} \mathrm{BP}$ and that approximately $60 \%$ of the saturated thickness in some parts of the HPA contained water recharged more than $9 \mathrm{ka}$, (uncalibrated 14-C ages) (McMahon et al., 2004a). Thus, recharge rates during the Early Holocene were larger than those in the Late Holocene (McMahon et al., 2004a). Vertical gradients in apparent groundwater age illustrate how the construction and operation of high-capacity wells can mix water from different depths of the aquifer. The large percentage of palaeorecharge in the HPA indicates the non-renewable nature of this heavily used groundwater resource (McMahon et al., 2004a).

\section{Oceania}

The Great Artesian Basin (GAB) of Australia is a confined groundwater basin composed of Mesozoic sandstones units separated and overlain by impervious marine mudstone and siltstones of Triassic, Jurassic and Cretaceous age.

The GAB is an iconic aquifer system of both national and international significance. With a total storage volume of $8.7 \times 10^{6} \mathrm{~m}^{3}$, it is the largest water storage in Australia covering $22 \%$ of the Australian continent $\left(1.7 \times 10^{9} \mathrm{~m}^{2}\right)$ (Fig. 9) and among the largest groundwater basins in the world. Around $40-50 \%$ of the water is

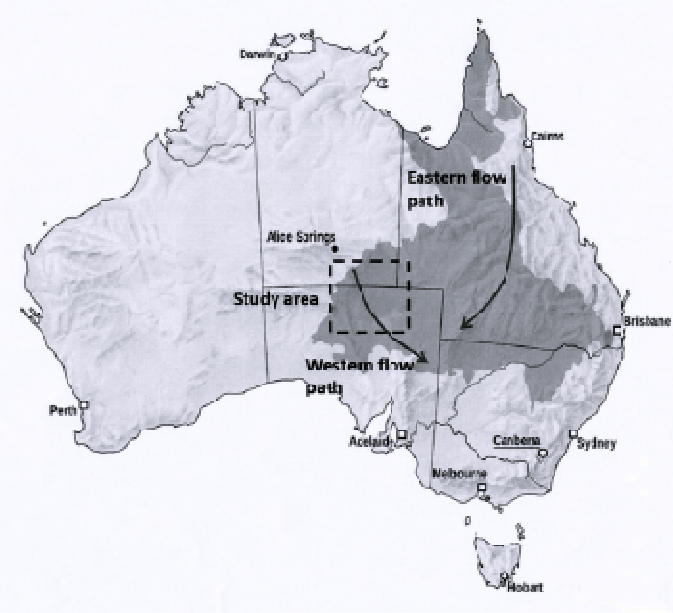

Figure 9. Location of the Great Artesian Basin (GAB; grey shaded area) and study area for ${ }^{81} \mathrm{Kr}$ analyses in the western Eromanga basin (striped rectangle). Arrows indicate the general direction of groundwater flow in the eastern and western part of the basin (modified after Wikipedia). potable i.e. with a salinity of less than $1000 \mathrm{mg} \mathrm{L}^{-1}$. Groundwater resources in the GAB support many activities including pastoral, agricultural, mining and extractive industries and inland population centers - and the demand for groundwater is growing. Over the last decades, $40 \%$ of springs have stopped flowing in the Eastern GAB due to extensive pumping (Love et al., 2013). Properly managing these groundwater resources, for often competing interests, requires a better understanding of how the groundwater basin works. Important research questions are the potential impacts of climate change and resource development on those water resources (Smerdon et al., 2012).

A recent research project was carried out in the frame of an extensive re-evaluation of the hydro- geochemistry of the Western Eromanga Basin (Love et al., 2013). This part of the GAB is characterized by very arid climate with mean annual rainfall between $130-230 \mathrm{~mm} \mathrm{a}^{-1}$. Typically ephemeral rivers are draining the area towards the central Lake Eyre basin (Radke et al., 2000).

The main confined aquifer in the region is the Jurassic Algebuckina aquifer (Habermehl, 1980; Love et al., 2000), which comprises unconsolidated sandstone with inter-embedded shales and mudstones and can reach a thickness in excess of $1,000 \mathrm{~m}$.

In the investigated part of the GAB groundwater forms the only reliable water supply for the local community and so there is a need to understand rates and mechanism of groundwater recharge. Environmental dating tracers (i.e. ${ }^{85} \mathrm{Kr},{ }^{39} \mathrm{Ar},{ }^{14} \mathrm{C},{ }^{81} \mathrm{Kr},{ }^{36} \mathrm{Cl}$ ) (Purtschert et al., 2013) in combination with indicators of environmental recharge conditions like stable isotopes of the water molecules or the concentration of dissolved chloride allow for a temporal and spatial evaluation of origin and rates of groundwater flow (Lehmann et al., 2002). Our results are consistent with a large spectrum of tracer ages ranging from modern to hundreds of thousands years (Purtschert et al., submitted). Along the flow path, $\mathrm{Cl}$ concentrations increase in direction of groundwater flow (Fig 10). ${ }^{81} \mathrm{Kr}$ and ${ }^{36} \mathrm{Cl}$ data were used to distinguish between evaporative enrichment during recharge and subsurface $\mathrm{Cl}$ accumulation due to rock water interaction or diffusive exchange with the aquitard. It is shown that in the Western part of the GAB a changing recharge regime is responsible for the larger fraction of the observed $\mathrm{Cl}$ variations

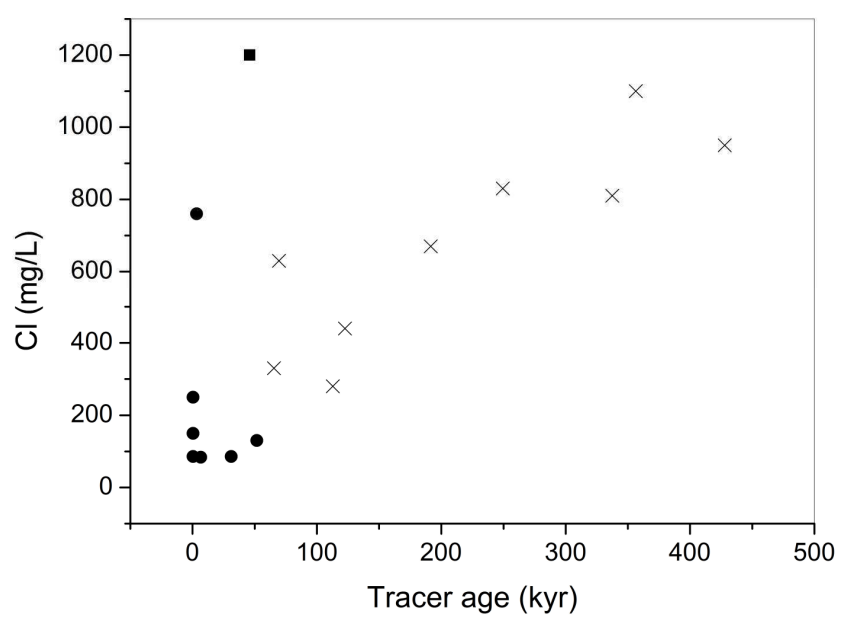

Figure 10. Concentration of dissolved chloride as function of tracer age in the J aquifer of the Western GAB. Lowest concentrations are observed for young water close to the recharge area (round symbols) and increase toward the centre of the basin (crossed symbols). 


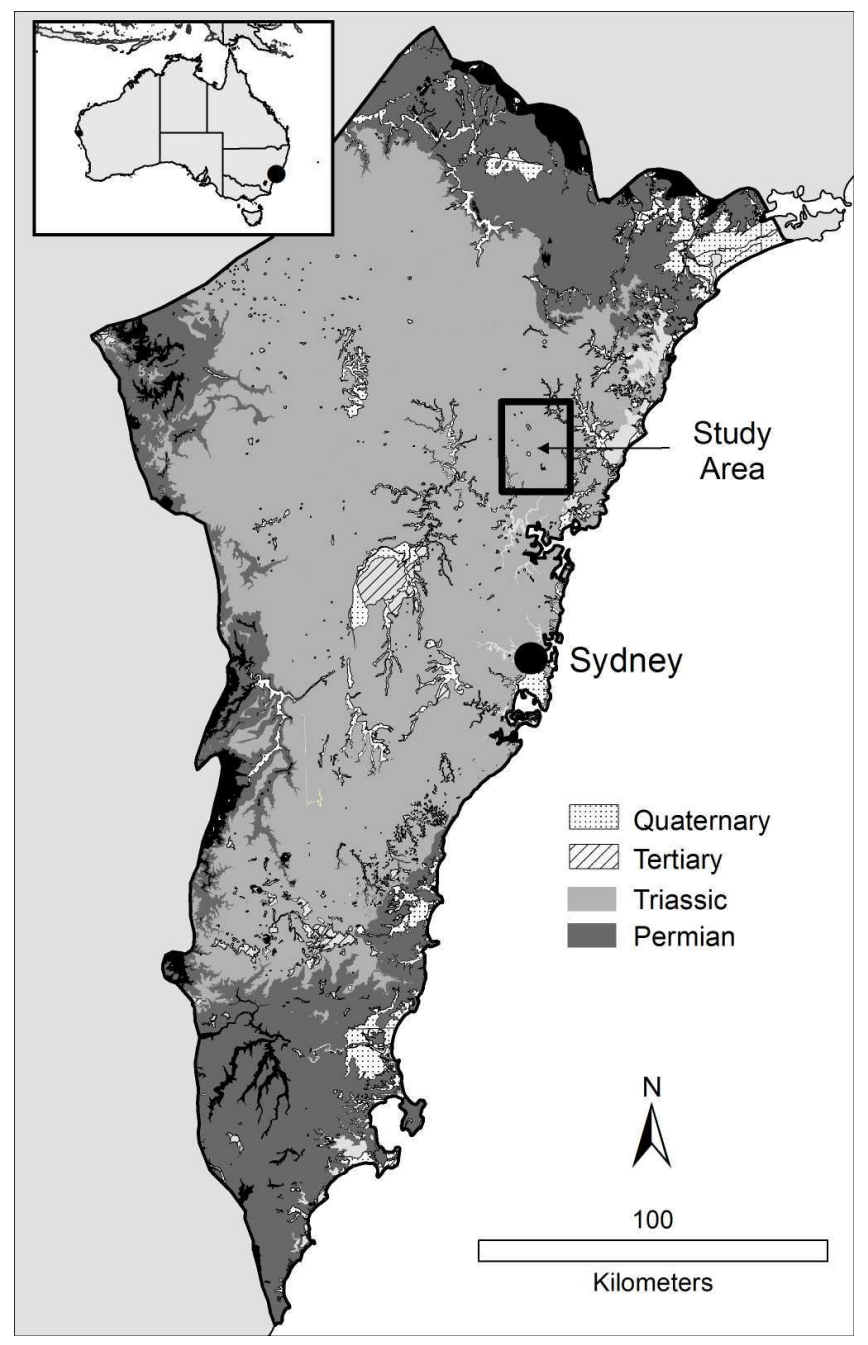

Figure 11. Location of the Sydney Basin showing simplified geology and the location of the Kulnura-Mangrove Mountain study site.

(Fig. 10). This is also confirmed by more positive $\delta^{2} \mathrm{H}$ and $\delta^{18} \mathrm{O}$ values for the oldest waters with mean residence times up to $450 \mathrm{ka}$. The younger and Holocene waters (solid symbols in Fig. 10) are characterized by lower $\mathrm{Cl}$ concentration and less enriched stable isotope signatures indicating a larger fraction of ephemeral river recharge.

The Permo-Triassic Sydney Basin covers $\sim 6.4 \times 10^{7} \mathrm{~m}^{2}$ of the eastern coast of SE-Australia with approximately $44 \%$ of this surface situated off-shore (Herbert, 1983) (Fig.11). Unlike other basins described, the siliciclastic aquifers in the Sydney Basin have only local importance as water resource. In general, only units like the Hawkesbury Sandstone and parts of the Narrabeen Group sandstones have been targeted for groundwater use. New studies related to gas exploration and exploitation has opened the opportunity to investigate groundwater below the traditional aquifers, exposing potentially older climatic signals. In general, recharge in the Sydney basin takes place in the elevated margins of the basin, including coastal outcrops. Groundwater flows towards the center of a bowl-shaped basin or discharges locally along broadly N-S trending fractures. The sandstone aquifers locally exhibit intense weathering with important porous aquifers that can range from 20 to $90 \mathrm{~m}$ in thickness. In depth a transition to a fracture groundwater flow dominated with dual porosity/ permeability characteristics occurs (McKibbin and Smith, 2000).

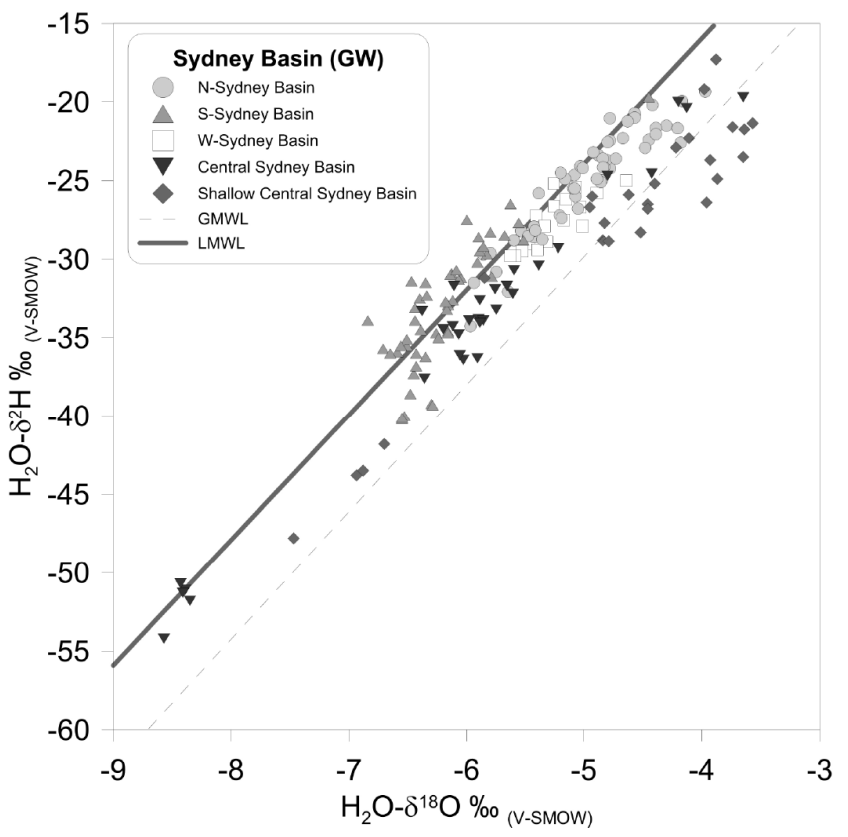

Figure 12. (A) $\delta^{2} H$ vs. $\delta^{18} O$ for groundwater in the Sydney Basin. The Global Meteoric Water Line (Craig, 1961) and the Local Meteoric Water Line (Hughes and Crawford, 2013) are included as reference. (B) Trend of slightly depleting groundwater $\delta^{18} \mathrm{O}$ isotopic values with increasing residence time for the $\mathrm{N}$-Sydney Basin area. Details of ${ }^{14} \mathrm{C}$ corrections and isotopic data from the $\mathrm{N}$-Sydney Basin can be found in Cendón et al. (2014), south Sydney and Metropolitan results are partly from Parsons Brinckerhoff (2006) and Kermode et al. (2014) respectively, the rest correspond to unpublished results.

An area within the Sydney Basin that has received particular attention is the Kulnura-Mangrove Mountain aquifer (Cendón et al. 2014). This is situated in an elevated plateau ( $300 \mathrm{~m}$ asl $)$ comprised predominantly of deeply weathered and fractured Hawkesbury Sandstone covering an area of $5.06 \times 10^{5} \mathrm{~m}^{2}$. Approximately $6 \times 10^{5} \mathrm{~m}^{3}$ $\mathrm{a}^{-1}$ of groundwater are authorised for extraction in the area with around $70 \%$ dedicated for commercial activities (irrigation, mineral water bottling, etc.). The geochemical dataset covers a multiple year record with the same wells sampled in detail for: major, minor and trace elements, ${ }^{14} \mathrm{C}$, water stable isotopes $\left(\delta^{18} \mathrm{O}, \delta^{2} \mathrm{H}\right),{ }^{3} \mathrm{H},{ }^{87} \mathrm{Sr} /{ }^{86} \mathrm{Sr}$ (Cendón et al., 2014). The high frequency time series reveals a dynamic groundwater system with sharp responses, particularly in groundwater residence times near pumped areas and a progressive trend to modern groundwater in subsequent samplings. The observed modernization could be linked to enhanced recharge during relatively wet conditions in the last $\sim 7$ years, coupled with the effect of pumping. Bores further away from intense pumping areas display stable conditions throughout all sampled years and provide palaeorecharge information.

Groundwater in the Sydney Basin preserves broad palaeoclimatic information and is very sensitive to local recharge conditions (rain shadows, altitude effects). No gaps in recharge have been identified with continuous recharge over the last $\sim 30 \mathrm{ka}$, as suggested from other areas in SE-Australia (Love et al., 1994; Currell et al., 2013). Water stable isotopes in the north part of the Sydney Basin suggest a slight trend to lower $\delta^{18} \mathrm{O}(\sim 1 \%)$ ) with increasing residence time (Fig. 12). This is consistent with expected lower recharge temperatures and broad model calculations from isotope-enabled general circulation 
models when comparing LGM and pre-industrial precipitation (Jasechko et al., 2015).

Recent work from speleothem records in Yarrangobilly ( 470 $\mathrm{km} \mathrm{SW}$ of Sydney) differentiate two periods of growth covering MIS5b and 5a with an increasing aridity trend resulting in a growth hiatus covering MIS4 and restarting growth during MIS3 (Webb et al., 2014). Groundwater records, at present, can only be compared to the later part of the speleothem record but also show increasing wet conditions in Sydney Basin data at about 5-6 ka. Deuterium excess (d-excess $=\delta^{2} \mathrm{H}-8 \delta^{18} \mathrm{O}$, Dansgaard 1964) in groundwater is like that of modern rainfall, suggesting similar sources of humidity and rainfall patterns over the last $\sim 15 \mathrm{ka}$.

\section{South America}

The Guarani Aquifer System $(G A S)$ is situated in aeolian and fluvial sandstones of continental origin deposited in Triassic and Jurassic times. The thickness of the sandstones ranges from few meters up to $800 \mathrm{~m}$ in Brazil and $600 \mathrm{~m}$ in Uruguay. The depth varies from ground surface to $1,800 \mathrm{~m}$ depth (the deepest site). The sandstones are generally covered by Cretaceous basaltic formations that provide different degrees of confinement. This thick basaltic package reduces the exposed areas of the sandstones to only $10 \%$. Therefore, depending on the locations, the aquifer system is both confined and unconfined (Montaño et al. 2004). The basalt thickness ranges from 200 to more than $1,000 \mathrm{~m}$.

GAS covers $\sim 1.1 \times 10^{9} \mathrm{~m}^{2}$ (68\% located in Brazil) and ranks among the World's largest fresh groundwater reservoirs. Underlying

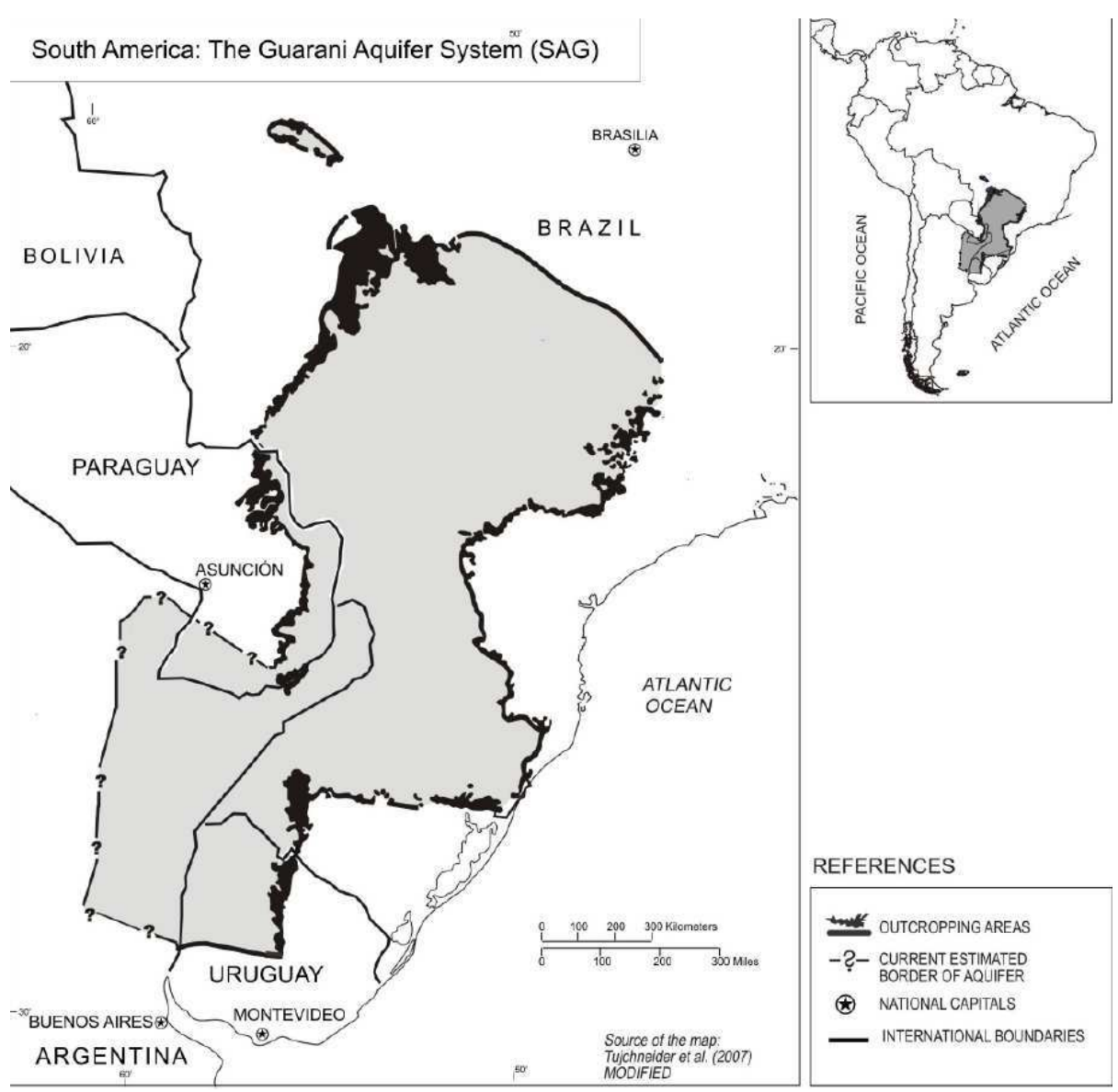

Figure 13. Extent of the Guaraní Aquifer System and political boundaries. a region of approximately 92 million inhabitants, the GAS is shared by four countries: Argentina, Brazil, Paraguay and Uruguay, which use this resource for very different purposes at varying exploitation levels (Fig. 13). An evaluation of groundwater use from the GAS indicates a withdrawal of about $1,04 \times 10^{9} \mathrm{~m}^{3} \mathrm{a}^{-1}$ mainly in Brazil where almost $90 \%$ of the current extraction occurs, particularly in São Paulo State.

Other distinctive characteristics of the GAS include artesian pressures and high yields at many locations $\left(500 \mathrm{~m}^{3} \mathrm{~h}^{-1}\right.$ where the aquifer is thickest), good quality groundwater (average salinity of $300 \mathrm{mg} \mathrm{L}^{-1}$ ), and temperatures ranging from $38^{\circ} \mathrm{C}$ to $60^{\circ} \mathrm{C}$ due to the local geothermal gradient. The unconfined zones are characterized by $\mathrm{Ca}-\mathrm{HCO}_{3}$-type water, while the confined areas have a $\mathrm{Na}-\mathrm{HCO}_{3}-$ type composition (Montaño et al., 1998).

According to Tujchneider et al. (2007) this aquifer system presents geological and structural discontinuities, as well as quality and groundwater age variations. Based on published investigations in the four countries, groundwater age ranges from recent waters (near water recharge areas) to groundwaters with residence times greater than $40 \mathrm{ka}$. Isotopic data also show that an important part of the present recharge area of the GAS becomes part of the local flow systems that eventually feed the surface channels.

The comprehensive hydrological study of the GAS supported by GEF (2009) included the use of isotopes $\left({ }^{3} \mathrm{H}, \delta^{18} \mathrm{O} / \delta^{2} \mathrm{H}, \delta^{14} \mathrm{C} / \delta^{13} \mathrm{C}\right.$, $\delta^{34} \mathrm{~S}$ ) to assess water quality and risk of contamination, and to determine the age and origin of groundwater with an integrated regional approach. The isotopic values of GAS groundwater have different behavior in the northern and southern areas of the aquifer. The $\delta^{18} \mathrm{O}$ values range from -5.3 to $-10.2 \%$ o in the northern part of the aquifer and between from -4.3 to $-7 \%$ in the southern zone. The values of $\delta^{2} \mathrm{H}$ are -33 to $-72 \%$ o and -31 to $-44 \%$ for the northern and southern zones, respectively. The groundwater samples of the northern part indicate limited evaporation process in the recharge zones and more precisely in the confined portion located in São Paulo and Mato Grosso States. The groundwater samples indicate that the waters would not be of recent origin, but have reached the aquifer under cooler and probably wetter conditions than the current weather conditions. Regarding to ${ }^{14} \mathrm{C}$ the highest values were found in the recharge areas and the lowest in the central part where the aquifer is deepest.

According to Hirata et al. (2011) some ${ }^{14} \mathrm{C}$ ages in the deep confined zone of São Paulo State (Brazil) are at the limit of the applicability of ${ }^{14} \mathrm{C}$ - based dating. More depleted values of $\delta^{2} \mathrm{H}$ and $\delta^{18} \mathrm{O}$ in the deep confined zone indicate the impact of recharge under a colder climate. The GAS is a completely "storage-dominated" system with old or very old groundwater in almost its total confined extent. Such a storage-dominated system, associated with increasing groundwater demand, could represent a real risk of 
supply shortage if correct aquifer management is not applied. We believe these findings have application for the entire GAS.

In 2010, the four countries that share the GAS have signed an agreement to develop management and protection actions within a framework of cooperation and understanding.

\section{Discussion and conclusion}

All the seven flag basins contain palaeo-water recharged during climates different from today. The most distinct signal is the low $\delta^{18} \mathrm{O}$ and $\delta^{2} \mathrm{H}$ values for water from the cool Late Weichselian (MIS2) followed by the higher values in water recharged during of the much milder Early Holocene. These signals are verified by ${ }^{14} \mathrm{C}$ age dating of the groundwater. In Africa the transition from the end of the Pleistocene to the Holocene is also associated with a much wetter climate, as has earlier been shown in terrestrial and marine palaeoclimate records (e.g. de Menocal et al., 2000). This wet period terminated abruptly (west Sahara, de Menocal et. al, 2000) or gradually (central and east Sahara, Krôpelin et al., 2008) towards the end of the Middle Holocene. The Holocene African Humid Period was long (more than $5 \mathrm{ka}$ ) and wet enough to give a widespread age signal in the western part of NWSAS. Also in other basins groundwater recharge in the Early and/or Middle Holocene is identified. In the HPA much of the water is older than $9 \mathrm{ka}$ (radiocarbon years), and water up to ages of $14 \mathrm{ka}$ (radiocarbon years) has been reported. In NCA the groundwater in the upper part of the basin is of Holocene age. The present available data from BAB, the Sydney Basin and GAS reveals some continental differences in the Late Pleistocene (MIS2) and Holocene (MIS1) recharge conditions.

In most groundwater basins there are no or few safe age records of water recharged before MIS2, as most age determinations are still based on the ${ }^{14} \mathrm{C}$-method, which for water can be used only back to ca. $30 \mathrm{ka}$ BP. New age determinations of water based on ${ }^{36} \mathrm{Cl}$ and ${ }^{83} \mathrm{Kr}$ indicate that some groundwater in NCP may have recharged already $770 \mathrm{ka} \mathrm{BP}$ (MIS 17, Middle Pleistocene) and in BAB as far back as 1.3 Ma BP. A residence time of $1 \mathrm{Ma}$ is also assumed as the transit time for water in NWSAS. There, water in some deeper parts of the CI aquifer, far from the present recharge area, is from older interglacial ages (MIS 5 and MIS11). A model based on ${ }^{36} \mathrm{Cl}$ indicates that the recharge intensity in MIS5 and MIS11 exceeds that of the Holocene humid period. Lang and Wolff (2011) have documented that MIS11 and MIS5 were two particularly wet Pleistocene interglacials, which seem to accord with the data from NWSAS.

In the $\mathrm{BAB}$, recharge is closely connected to the melting of overlying ice during Pleistocene glaciations and perhaps much less to the atmospheric climate at the time when the ice melted. It is obviously not straight forward to correlate records from glaciated areas with those from areas that were ice-free. Both in NWSAS and the Sydney Basin the local variations are large. Modern water mixed with palaeowater is found close to pumping sites, while palaeowater dominates further away from disturbed areas.

High recharges are needed to give clear palaeosignals in the seven "flag basins". The best signal would be created if a wet period is followed by a dry period without significant recharge, like in northern Africa in the Holocene. In general, one can probably only expect to identify millennium-scaled moist palaeoclimate events. Today the understanding of the groundwater recharge history of the basins as described in this paper is very limited. More age determinations and a wider use of different dating methods and palaeoclimate indicators will probably increase this understanding considerably in the near future. In NWSAS, NCP, GAB and BAB palaeogroundwater ages are from some thousand up to more than a million years. If the sampling of water for palaeogroundwater studies is intensified, there may be a potential to establish long recharge records in these basins.

There is a need for a continuous correlation between palaeogroundwater data and data from terrestrial palaeorecords. However, while shorter moist periods can be identified as sharp peaks in terrestrial, high-resolution records, these may not necessarily give any signals in low-resolution groundwater data series. Therefore, highresolution records spanning some few millennia may not always help to understand the long-term recharge history of large aquifers. Correlation between different groundwater records on a local, regional and continental scale may perhaps prove to be more useful in studies of palaeorecharge processes.

One may question if the study of palaeogroundwater signals is of any importance in applied groundwater studies. As documented in this paper, palaeowater may dominate in many groundwater basins where the extraction of water exceeds the present recharge. We believe that it will become increasingly important in water supply planning to know the vertical and lateral age variation in groundwater aquifers. The study in NWSAS is a good example of this, showing that the age of the water extracted for irrigation and human water consumption is increasing over time. NWSAS, BAB and GAS and many other large groundwater basins are shared between different countries. Therefore, knowledge about the age of extractable water in the different countries may be used in the integrated management planning of such shared aquifer resources.

\section{Acknowledgement}

Financial support to for the years 20011-2015 was provided by IUGS/UNESCO, through their joint program IGCP (IGCP-618), from INQUA, and from UNESCO-IHP, through the project GRAPHIC. The research in each individual research basin has been financed by national funding agencies. Prof. Chris Harris, Univ. of Cape Town and prof. Werner Aeschbach-Hertig, Heidelberg Univ. reviewed the submitted manuscript and suggested useful changes, which improved the paper. To these organisations and persons we render our sincere thanks.

\section{References}

Abid, K., Dulinski, M., Ammar, F.H., Rozanski, K., and Zouari, K., 2012, Deciphering interaction of regional aquifers in Southern Tunisia using hydrochemistry and isotopic tools: Applied Geochemistry, v. 27, no. 1, pp. $44-55$.

Aeschbach-Hertig and Gleeson, 2012, Regional strategies for the accelerating global problem of groundwater depletion. Nature Geosci. v. 5, pp. no. $12,853-861$

Cendón, D. I., Hankin, S. I., Williams, J. P., Van der Ley, M., Peterson, M., Hughes, C. E., Meredith, K., Graham, I. T., Hollins, S. E., Levchenko, V., and Chisari, R., 2014, Groundwater residence time in a dissected and weathered sandstone plateau: Kulnura-Mangrove Mountain aquifer, NSW, Australia: Australian Journal of Earth Sciences, v. 61, no. 3, pp. 475-499

Chen, J.Y., 2010, Holistic assessment of groundwater resources and regional environmental problems in the North China Plain: Environmental Earth Science, v. 61, no, 5, pp. 1037-1047.

Chen, J.Y., Tang, C.Y., Sakura, S., Kondoh, A., Yu, J.J., Shimada, J., and Tanaka. T., 2004, Spatial geochemical and isotopic characteristics associated with groundwater flow in the North China Plain: Hydrological Processes, v.18, no. 13, pp. 3133-3146. 
Craig, H., 1961, Isotopic variation in meteoric waters: Science, v. 133, no. 3465, pp. 1702-1703.

Currell, M., Cendón, D., and Cheng, X., 2013, Analysis of environmental isotopes in groundwater to understand the response of a vulnerable coastal aquifer to pumping: Western Port Basin, south-eastern Australia: Hydrogeology Journal, v. 21, no. 7, pp. 1413-1427.

Dansgaard, W., 1964, Stable isotopes in precipitation:Tellus B, v. 16, pp. $436-468$

Dassi, L., Zouari, K., and Faye, S., 2005, Identifying sources of groundwater recharge in the Merguellil basin (Tunisia) using isotopic methods: implication of dam reservoir water accounting: Environmental Geology, v. 49 , no. 1 , pp. 114-123.

de Menocal, Ortiz, J., Guilderson, T., Adkins, J., Sarnthein, M., Baker, L., and Yarusinsky, M., 2000, Abrupt onset and termination of the African Humid Period: rapid climate responses to gradual insolation forcing: Quaternary Science Reviews, v. 19, no. 1-5, pp. 347-361.

Dennehy, K.F., Litke, D.W., McMahon, and P.B., 2002, The High Plains aquifer; USA - Ground-water development and sustainability, inHiscock, K.M., Rivett, M.O., and Davison, R.M., eds, Sustainable ground-water development: Geological Society of London Special Publication, v. 193, pp. 99-119.

Dong, Y.A., He M., Jiang, S.S., Wu, S.Y., and Jiang, S., 2002. (in Chinese with English abstract): Earth Science Journal of China, University of Geosciences, v.. 27, no.1, pp. 105-109.

Dykoski, C.A, Edwards, R.L., Cheng, H., Yuan, D.X., Cai, Y.J., Zhang, M.L., Lin, Y.S., Qing, J.M., An, Z.S., and Revenaugh, J., 2005, A highresolution, absolute-dated Holocene and deglacial Asian monsoon record from Dongge Cave, China: Earth and Planetary Science Letters, v. 233, no. $2-3$, pp. $71-86$.

Edmunds, W.M., Guendouz, A.H., Mamou, A., Moulla, A., Shand, P., and Zouari, K., 2003, Groundwater evolution in the Continental Intercalaire aquifer of southern Algeria and Tunisia: trace element and isotopic indicators: Applied Geochemistry, v. 18, no. 6, pp. 805-822.

Edmunds, W.M., Dodo, A., Gasse, F., Gaye, C.B., Goni, I.B., Travi, Y., Zouari, K. and Zuppi, G.M., 2004, Groundwater as an archive of climatic and environmental change: Europe to Africa, in: Battarbee, R.W., Gasse, F., Stickley, C.E., eds.: Past Climate Variability Through Europe and Africa. Springer, Dortrecht, pp. 279-324.

Gerber, C., Vaikmäe,R., Purtschert,R., Leuenberger,M.,Raidla,V., Lu, Z., Aeschbach, W., Weissbach, T., Waber, N., Mokrik, R., Babre, A., Saks, T., 2016, Using $81 \mathrm{Kr}$ and noble gases to characterize and date groundwater and brines in the Baltic Artesian Basin on the 1 million years timescale: EPSL (submitted).

GEF, 2009, Serie "Manuales y Documentos Técnicos del Proyecto para la Protección Ambiental y Desarrollo Sostenible del Sistema Acuífero Guaraní".

Gurdak, J.J., 2008, Ground-water vulnerability: nonpoint-source contamination, climate variability, and the high plains aquifer: VDM, Saarbrucken, Germany, 223 pp.

Gurdak, J.J., Walvoord, M.A., and McMahon P.B., 2008, Susceptibility to enhanced chemical migration from depression-focused preferential flow, High Plains aquifer: Vadose Zone Journal, v 7, no. 4, pp. 1-13.

Gurdak, J.J., McMahon, P.B., Dennehy, K.F., and Qi S.L., 2009, Water quality in the High Plains Aquifer, Colorado, Kansas, Nebraska, New Mexico, Oklahoma, South Dakota, Texas, and Wyoming,1999-2004: US Geological Survey Circular, no. 1337, 63 pp.

Gurdak, J.J., and Roe, C.D., 2010, Review: Recharge rates and chemistry beneath playas of the High Plains aquifer, USA: Hydrogeology Journal, v. 18 , no. 7 , pp. $1747-1772$.

Gurdak, J.J., McMahon, P.B., and Bruce, B.W. , 2012, Vulnerability of groundwater quality to human activity and climate change and variability, High Plains aquifer, USA, in Treidel, H., Martin-Bordes, J.J., and Gurdak, J.J., eds., Climate change effects on groundwater resources: A global synthesis of findings and recommendations: International Association of Hydrogeologists (IAH) - International Contributions to Hydrogeology, Taylor \& Francis publishing, company ISBN 978-0415689366. pp. 145167.

Habermehl, M.A., 1980, The Great Artesian Basin, Australia: Journal of Australian Geology \& Geophysics, v. 5, pp. 9-38.

Herbert, C., 1983, Geology of the Sydney 1:100 000 Sheet 9130: Geological Survey of New South Wales, NSW Department of Mineral Resources, p. 225.
Hirata, R., Gesicki, A., Sracek, O., Bertolo, R., Giannini, P.C., Ramón Aravena, R., 2011, Relation between sedimentary framework and hydrogeology in the Guarani Aquifer System in São Paulo state, Brazil: Journal of South American Earth Sciences, v. 31, no. 4, pp. 444-456.

Houcine, J., Ammar, F.H., Kamel, A., Kamel, Z., and Aggoune, A., 2014. Study of RejimMaatoug groundwater in southern Tunisia using isotope methods: Journal of Hydro-environment Research 8, no. 3, pp. 316-327.

Hughes, C.E., Crawford, J., 2013. Spatial and temporal variation in precipitation isotopes in the Sydney Basin, Australia. Journal of Hydrology, 489: 42-55.

Jasechko, S., Lechler, A., Pausata, F. S. R., Fawcett, P. J., Gleeson, T., Cendón, D. I., Galewsky, J., LeGrande, A. N., Risi, C., Sharp, Z. D., Welker, J. M., Werner, M., and Yoshimura, K., 2015, Glacial-interglacial shifts in global and regional precipitation ä180: Climate of th. Past Discussions, v. 11 , no. 2 , p. $831-872$.

Jöeleht, A., Kukkonen, and I.T., 1998, Thermal properties of granulite facies rocks in the Precambrian basement of Finland and Estonia: Tectonophysics, v. 291. No. 1-4, pp. 195 - 203.

Kalm, V., Raukas, A., Rattas, M., and Lasberg K. 2011, Pleistocene Glaciations in Estonia, in J.Ehlers, Gibbard, J.P.L., and Hughes, P.D., eds: Quaternary Glaciations - Extent and Chronology. A Closer Look: Developments in Quaternary Science, v. 15, Elsevier, Amsterdam, pp. 95 - 104.

Kamel, S., Dassi, L., Zouari, K., and Abidi, B., 2005, Geochemical and isotopic investigation of the aquifer system in the Djerid-Nefzaoua basin, Southern Tunisia: Environmental Geology, v. 49, no. 1, pp. 159170

Karro, E., Marandi, A., and Vaikmäe, R., 2004, The origin of increased salinity in the Cambrian-Vendian aquifer system on the Kopli Peninsula, northern Estonia: Hydrogeology Journal, v. 12, no. 4, pp. 424 - 435.

Kermode, S., Cendón, D., Hankin, S. and Russell, G.,2014, 'Age', recharge rates and connectivity of groundwater in deeper aquifers of the Sydney Basin: Proceedings Aust Earth Sciences Convention 2014, Geological Society of Australia Abstracts No. 110. P. 223. ISSN 0729 011X.

Konikow L.F., and Kendy E., 2005, Groundwater depletion: A global problem. Hydrogeology Journal, v. 13, pp. 317-320.

Kraiem, Z., Zouari, K., Chkir, N., and Agoune, A., 2014, Geochemical characteristics of arid shallow aquifers in Chott Djerid, south-western Tunisia: Journal of Hydro-environment research, v. 8, no. 4, pp.460473

Kreuzer, A.M., von Rohden, C., Friedrich, R., Chen, Z.Y., Shi, J.S., Hajdas, I., Kipfer, R., and Aeschbach-Hertig, W., 2009, A record of temperature and monsoon intensity over the past $40 \mathrm{kyr}$ from groundwater in the North China Plain: Chemical Geology, v. 259, no. 1-2, pp. 168-180.

Kröpelin, S., Verschuren, D., Lézine, A.-M., Eggermont, H., Cocquyt, C.,Francus, P., Cazet, J.-P., Fagot, M., Russell, J. M., Darius, F., Conley, D. J., Schuster, M., von Suchodoletz, H., Engstrom, D. R., 2008, ClimateDriven Ecosystem Successionin the Sahara: The Past 6000 Years: Science 320, no. 765 , pp. $765-768$.

Kuper, R., and Kröpelin, S., 2006, Climate-controlled Holocene occupation of the Sahara: motor of Africa's evolution, Science, v. 313 no. 5788, pp. 803-807.

Lang, N., and Wolff, E. W., 2011, Interglacial and glacial variability from the last $800 \mathrm{kyr}$ in marine, ice and terrestrial archives: Climate of the Past, v. 7, no. 2, pp. 361-380.

Lehmann, B.E., Purtschert, R., Loosli, H.H., Love, A., Collon, P., Kutschera, W., Beyerle, U., Aeschbach-Hertig, W., Kipfer, R. and Frape, S.K., 2002, ${ }^{81} \mathrm{Kr}$-calibration of ${ }^{36} \mathrm{Cl}$ - and ${ }^{4} \mathrm{He}$-evolution in the western Great Artesian Basin, Australia: Geochimica et CosmochimicaActa, Davos, v. 66, no. $15 \mathrm{~A}$, p. A445

Love, A., Wohling, D., Fulton, S., Rousseau-Gueutin, P. and Ritter, S., 2013, Groundwater recharge, hydrodynamics and hydrochemistry of the Western Great Artesian Basin, in Government, A. ed,, Allocating Water and Maining Springs in the Great Artesian Basin, p. 237.

Love, A. J., Herczeg, A. L., Leaney, F. W. J., Stadter, M. F., Dighton, J. C., and Armstrong, D., 1994, Groundwater residence time and palaeohydrology in the Otway Basin, South Australia: ${ }^{2} \mathrm{H},{ }^{18} \mathrm{O}$ and ${ }^{14} \mathrm{C}$ data: Journal of Hydrology, v. 153, no. 1-4, pp. 157-187.

Love, A.J., Herczeg, A.L., Samson, L., Cresswell, R.G. and Fifield, L.K., 2000, Sources of chloride and implications for $36 \mathrm{Cl}$ dating of old groundwater, South Western Great Artesian basin, Australia: Water Resurces Research, v. 36 , no. 6 , pp. $1561-1574$. 
Maupin M.A., and Barber N.L., 2005, Estimated withdrawals from principal aquifers in the United States, 2000: US Geolological Survey Circular, no. 1279,46 pp.

McKibbin, D. and Smith, P. C., 2000, Sandstone hydrogeology of the Sydney region, in McNally, G. H., and Franklin B. J. eds. Sandstone city, Sydney's dimension stone and other sandstone geomaterials: Environmental Engineering and Hydrogeology Specialist Group (EEHSG), Geological Society of Australia, Monograph, no. 5, pp. 8397.

McGuire, V.L., 2007, Changes in water levels and storage in the High Plains aquifer, predevelopment to 2005: US Geological Survey Fact Sheet. No. 2007-3029, 2 pp.

McGuire, V.L., Johnson, M.R., Schieffer, R.L., Stanton, J.S., Sebree, S.K., and Verstraeten, I.M., 2003, Water in storage and approaches to groundwater management, High Plains aquifer, 2000: US Geological Survey Circular, no. 1243, 51 pp.

McMahon, P.B., Dennehy, K.F., Bruce, B.W., Gurdak, J.J., and Qi, S.L., 2007, Water-quality assessment of the High Plains aquifer, 1999-2004: US Geological Survey Professional Paper, no. 1749, 136 pp.

McMahon, P.B., Böhlke, J.K., and Christenson. S.C., 2004a, Geochemistry, radiocarbon ages, and paleorecharge condi-tions along a transect in the central High Plains aquifer, southwestern Kansas, USA: Applied Geochemistry, v. 19, no. 7, pp. 1655-1686.

McMahon, P.B., Böhlke, J.K., and Lehman, T.M., 2004b, Vertical gradients in water chemistry and age in the south-ern High Plains aquifer, Texas, 2002: U.S. Geological Survey Scientific Investigations Report, no. 2004$5053,53 \mathrm{p}$

Mokrik R., 1997, The Palaeohydrogeology of the Baltic Basin. Vendian \& Cambrian: Tartu University Press. Tartu, 138 pp.

Montaño, J., Tujchneider, O., Aug,e M., Filí, M., Paris, M., D’Elía, M., Perez, M., Nagy, M.I., Collazo, P., and Decoud, P., 1998, Acuíferos Regionales en América Latina. Sistema Acuífero Guaraní. Capítulo ArgentinoUruguayo: Centro Internacional de Investigaciones para el Desarrollo de Canadá (C.I.I.D.) y Centro de Publicaciones de la Universidad Nacional del Litoral. Santa Fe, Argentina. Santa Fe, Argentina.

Montaño, J., Da Rosa Filho, E., and Hernandez, M., 2004, Características hidrogeológicas del Sistema Acuífero Guaraní. http://www.alhsud.com/ castellano/articulos_listado.asp. Cited 01 Abr 2004

OSS, 2003, Systèmeaquifère du Sahar Septentrional: une conscience de bassin. Observatoire du Sahara et du Sahel, 2nd Edition, 2003 http://www.ossonline.org

Parsons Brinckerhoff, 2006, Hydrochemical and environmental isotope program- Upper Nepean groundwater investigation sites, Published on Metropolitan Water Plan Groundwater CD in 2009, Volume 2, Sydney Catchment Authority, Penrith.

Petersen,J.O., Deschamps, P., Hamelin, B., Goncalves, J., Michelot, J.-L. , Guendouz, A., Zouari, K. , 2014, Using $36 \mathrm{Cl}$ data to quantify the paleorecharge in arid region. Example of the North Western Saharan Aquifer System: Geophysical Research Abstracts, 16, EGU2014-15996.

Punning, J.M., Toots, M., Vaikmäe, R., 1987, Oxygen-18 in Estonian natural waters: Isotopenpraxis, v, 23, no. 6, pp. 232-234.

Purtschert, R., Love, A., Lu, Z.T., Fulton, S., Shand, P., Jiang, W., Wohling, D., Aeschbach Hertig, W., 2016, Dating old groundwater by multiple tracers including Krypton-81: A case study in the Great Artesian Basin, Australia (submitted)

Purtschert, R., Sturchio, N.C. and Yokochi, R., 2013, Krypton-81 dating of old groundwater, in Suckow, A., Aggarwal, P., and Araguas-Araguas, L., eds, Isotope methods for dating old groundwater: IAEA, Vienna, pp. 91124.

Radke, B.M., Ferguson, J., Cresswell, R.G., Ransley, T.R. and Habermehl, M., 2000, Hydrochemistry and implied hydrodynamics of the Cada-owieHooray aqufer GAB: Bureau of Rural Sciences, Australia.

Raidla, V., Kirsimäe, K., Vaikmäe, R., Kaup, E., and Martma, T., 2012, Carbon isotope systematics of the Cambrian-Vendian aquifer system in the northern Baltic Basin: Implications to the age and evolution of groundwater: Applied Geochemistry, v. 27, no. 10, pp. 2042-2052.

Ricardo, H., Gesicki, A., Sracek, O., Bertolo, R., Giannini, P.C, and Aravena, R., 2011, Relation between sedimentary framework and hydrogeology in the Guarani Aquifer System in São Paulo state, Brazil: Journal of South American Earth Sciences, v. 31, no. 4, pp. 444-456.

Smerdon, B., Welsh, W. and Ransley, T., 2012, Water resource assessment for the Western Eromanga region. A report to the Australian Government from the CSIRO Great Artesian Basin Water Resource Assessment. $120 \mathrm{pp}$.

Tujchneider, o., Perez. M., Paris, M., Elia, M.D., 2007, The Guarani aquifer system, in, deMarsilyGhislain, L.C., Aquifer systems management: International Association of Hydrogeologists, selected papers 10, ch. 18, pp. 239-252.

Vaikmäe, R., Vallner, L., Loosli, H.H., Blaser, P.C., Juillard-Tardent, M., 2001, Palaeogroundwater of glacial origin in the Cambrian-Vendian aquifer of northern Estonia, in Edmunds, W.M., and Milne, C.J., eds, Palaeowaters of Coastal Europe: Evolution of Groundwater since the late Pleistocene: Geological Society, London, Special Publications, v. 189 , pp. $17-27$.

Virbulis,J., Bethers,U., Saks,T., Sennikovs, J., and Timuhins, A., 2013, Hydrogeological model of the Baltic Artesian Basin: Hydrogeology Journal, v. 21, no. 4, pp. 845-862.

Wang, Y.J., Cheng, H., Edwards, R.L., An, Z.S, Wu, J.Y., Shen, C.C., and Dorale, J.A., 2001, A High-Resolution Absolute-Dated Late Pleistocene Monsoon Record from Hulu Cave, China: Science, v. 294, no. 5550, pp. 2345-2348.

Webb, M., Dredge, J., Barker, P. A., Müller, W., Jex, C., Desmarchelier, J., Hellstrom, J., and Wynn, P. M., 2014, Quaternary climatic instability in south-east Australia from a multi-proxy speleothem record: Journal of Quaternary Science, v. 29, no. 6, pp. 589-596.

Wei, W, Chen, Z.Y., Zhao, H.M., Liu, J., and Wang, Y., 2011, Comparison of $4 \mathrm{He}$ and 14C Dating of Groundwater from Quaternary Confined Aquifers in Hebei Plain: Journal of Jilin University (Earth Science Edition), v. 41, no. 4, pp. 1144-1150 (in Chinese with English abstract)

Wu, C, Xu, Q.H., Zhang, X.Q., and Ma, Y.H., 1996, Paleochannels on the North China Plain: types and distributions. Geomorphology, v. 18, pp. 5-14.

Xie, X.M., Guo, H.Y., Tang, K.W., Yin, M.W., 2002, Dual coupled model for integrated assessment of surface water and groundwater in North China Plain: ShuiliXuebao, v. 12, pp. 95-100 (in Chinese with English abstract)

Zhang, G.H., Chen, Z.Y., Fei, Y.H., 2000, Relationship between the formation of groundwater and the evolution of regional hydrologic cycle in North China Plain: Advices in Water Science, v. 11, no. 4, pp. 415-420 (in Chinese with English abstract).

Zuzevièius, A., 2010, The groundwater dynamics in the southern part of the Baltic Artesian Basin during the Late Pleistocene: Baltica, v. 23, no. 1, pp. 1-12. Vilnius. 